\title{
Retrospective study of rotavirus in beef and dairy herds in the State of São Paulo, Brazil
}

\author{
Estudo retrospectivo de rotavírus bovino em rebanhos leiteiros \\ e de corte no Estado de São Paulo, Brasil
}

\author{
Heloisa Pinto de Godoy Siqueira**, Ingrid Bortolin Affonso Lux Hoppe ${ }^{2}$, André Buzutti de Siqueira ${ }^{3}$ \& \\ Maria da Gloria Buzinaro² \\ 'Veterinary, Msc. Faculdade de Ciências Agrárias e Veterinárias - FCAV, Universidade Estadual Paulista - UNESP, Jaboticabal, \\ SP, Brasil \\ Veterinary, Dr. Faculdade de Ciências Agrárias e Veterinárias - FCAV, Universidade Estadual Paulista - UNESP, Jaboticabal, SP, \\ Brasil \\ ${ }^{3}$ Veterinary, Dr. Universidade Federal de Roraima - UFRR, Boa Vista, RR, Brasil
}

\begin{abstract}
Rotavirus is a major cause of neonatal diarrhea in cattle worldwide, leading to significant economic losses. This study aimed to determine the occurrence of rotavirus infection in 48 herds of dairy and beef cattle from 21 municipalities in the northern region of São Paulo State, Brazil during 2006-2010. A total of 803 fecal samples from calves aged 1-90 days were analyzed by polyacrylamide gel electrophoresis (PAGE), and positive samples were detected in 33.3\% (16/48) of the herds and 6.1\% (49/803) of the samples. Of the 326 samples from calves with diarrhea, 12.6\% (41/326) were positive, while only $1.7 \%$ (8/477) of the 477 samples from calves without clinical signs were positive. These results showed that there is a statistically significant association between the presence of diarrhea and rotavirus infection. Of the 35 dairy herds studied, 34.3\% (12/35) were positive for rotavirus, and 3.3\% (23/689) of the samples were positive. Of the samples from animals with diarrhea, 5.6\% (15/269) were positive, while 1.9\% (8/420) of the samples from animals without diarrhea were positive. Chi-square analysis showed a significant association between rotavirus detection and the presence of diarrhea in dairy herds. However, there was no statistical relationship between the age of the calves and rotavirus infection. Of the 13 beef herds sampled, 30.8\% (4/13) had positive animals, and 22.8\% (26/114) of the samples were positive. All of the positive animals had diarrhea (26/26), which resulted in undefined statistical association. However, the frequency of positive samples was significantly higher in calves aged 1-30 days $(p<0.05)$. According to the migration of the rotavirus genome in PAGE, it was possible to identify seven distinct electrophoretic types, characteristic of group A rotaviruses, showing genetic differences among the detected strains. The presence of rotavirus infections in the studied region emphasizes the importance of implementing control and prevention measures, since the agent is in constantly evolving in cattle herds.
\end{abstract}

Keywords: calves, diarrhea, electrophoretic profile, PAGE.

\section{Resumo}

O rotavírus é uma das principais causas de diarréia neonatal em bovinos em todo o mundo, levando a perdas econômicas significativas. Este estudo teve como objetivo determinar a ocorrência de infecção por rotavírus em 48 rebanhos leiteiros e bovinos de corte de 21 municípios da região norte do Estado de São Paulo, Brasil, no período de 2006 a 2010. Um total de 803 amostras fecais de bezerros com idade entre 1 e 90 dias foi analisado por eletroforese em gel de poliacrilamida (PAGE), e amostras positivas foram detectadas em 33,3\% (16/48) dos rebanhos e 6,1\% (49/803) das amostras. Das 326 amostras de bezerros com diarréia, 12,6\% (41/326) foram positivas, enquanto apenas 1,7\% (8/477) das 477 amostras de bezerros sem sinais clínicos foram positivas. Estes resultados mostraram que existe uma associação estatisticamente significativa entre a presença de diarreia e infecção por rotavírus. Dos 35 rebanhos leiteiros estudados, 34,3\% (12/35) foram positivos para rotavírus, e 3,3\% (23/689) das amostras foram positivas. Das amostras de animais com diarréia, 5,6\% (15/269) foram positivas, enquanto 1,9\% (8/420) das amostras de animais sem diarréia foram positivas. A análise qui-quadrado mostrou uma associação significativa entre a detecção de rotavírus e a presença de diarréia em rebanhos leiteiros. No entanto, não houve relação estatística entre a idade dos bezerros e a infecção por rotavírus. Dos 13 rebanhos bovinos amostrados, $30,8 \%$ (4/13) apresentaram animais positivos e 22,8\% (26/114) das amostras foram positivos. Todos os animais positivos tiveram diarréia (26/26), o que resultou em associação estatística indefinida. No entanto,
How tocite:Siqueira, H.P.G.,Hoppe,I.B.A.L., Siqueira, A. B., \& Buzinaro, M. G. (2018). Retrospectivestudy of rotavirus in beef and dairy herds in the State of São Paulo, Brazil. Brazilian Journal of Veterinary Medicine, 40, e091818. doi: 10.29374/2527-2179.bjvm091818

\section{Financial support: None}

Conflict of interests: No conflict of interests declared concerning the publication of this article.

Received: May 03, 2018.

Accepted: July 18, 2018.

The study was carried out at rotavirus Laboratório de rotaviroses, Faculdade de Ciências Agrárias e Veterinárias - FCAV, Universidade Estadual Paulista - UNESP, Jaboticabal, São Paulo, Brasil

\section{*Correspondence}

Heloisa Pinto de Godoy Siqueira

Departamento de Medicina Veterinária Preventiva, Universidade Estadual Paulista UNESP

Via de Acesso Prof.Paulo Donato Castellane $\mathrm{s} / \mathrm{n}$

CEP14884-900 - Jaboticabal (SP), Brasil

E-mail: helogodoy@hotmail.com
Copyright Siqueira et al. This is an Open Access article distributed under the terms of the Creative Commons Attribution Non-Commercial License which permits unrestricted non-commercial use, distribution, and reproduction in any medium provided the original work is properly cited. 
a freqüência de amostras positivas foi significativamente maior em bezerros com idade entre 1 e 30 dias $(p<0,05)$. De acordo com a migração do genoma do rotavírus no PAGE, foi possível identificar sete tipos eletroforéticos distintos, característicos dos rotavírus do grupo A, mostrando diferenças genéticas entre as cepas detectadas. A presença de infecções por rotavírus na região estudada enfatiza a importância da implementação de medidas de controle e prevenção, uma vez que o agente está em constante evolução em rebanhos bovinos.

Palavras-chave: bezerros, diarréia, perfil eletroforético.

\section{Introduction}

In Brazil, the cattle production chain is an important sector of agribusiness that has a direct impact on the national economy. Despite having the largest commercial herd in the world and being the largest exporter of beef, the productivity of Brazilian herds is considered low (Associação Brasileira das Indústrias Exportadoras de Carne, 2016). Poor sanitation is one of the factors responsible for the poor performance of Brazilian dairy and beef cattle, as such conditions can increase the occurrence of diseases in livestock that lead to economic losses.

Neonatal diarrhea is one of the most frequent diseases in calves and is the main cause of economic losses due to high mortality. Group A rotavirus is the most important diarrhea-causing agent (Holland, 1990; Saif et al., 1991). The high resistance of the rotavirus particle, ease of transmission among infected animals, genetic diversity of field samples, and the ability to infect a wide variety of hosts, make it difficult to control rotavirus infection (Dhama et al., 2009).

Rotavirus is a genus within the family Reoviridae. The viral particle consists of an icosahedral capsid, approximately $75 \mathrm{~nm}$ in diameter, without an envelope. The genome consists of 11 double-stranded RNA segments, each encoding at least one protein (Estes \& Kapikian, 2007). These 11 viral RNA segments, when separated by polyacrylamide gel electrophoresis (PAGE), yield a characteristic migration pattern (Estes \& Cohen, 1989). Thus, PAGE is often used in epidemiological studies of rotavirus infections, as differences in genomic profiles are an important aspect of infection (McNally \& Logan 1983).

Neonatal bovine rotavirus diarrhea has a complex epidemiology due to the circulation of different viral genotypes within a given geographical area. This genotype variation is primarily caused by point mutations and genomic rearrangements (Steele et al., 1995). In Brazil, studies conducted in several states have shown rotavirus as an important cause of diarrhea in calves, with a higher frequency of infection in animals up to 30 days of age (Alfieri et al., 2006).

Given the importance of this viral agent, the present retrospective study was conducted to determine the occurrence of rotavirus infection in dairy and beef cattle herds located in several municipalities in the northern region of São Paulo State during the period of 2006-2010, by using PAGE and analyzing the genome profile of the detected strains.

\section{Material and methods}

\section{Study summary}

The study was conducted over a five-year period (2006-2010), during which 803 samples of calf feces were obtained and analyzed at the Rotavirus Laboratory in Department of Preventive Veterinary Medicine and Animal Reproduction of the Faculty of Agrarian and Veterinary Sciences of Jaboticabal (FCAV/Unesp).

Fecal samples were collected from animals in 48 herds, including 35 dairy herds (689 samples) and 13 herds of beef cattle (114 samples). The samples were obtained from calves, aged 1-90 days, regardless of the presence of clinical signs of diarrhea. The cattle herds sampled were housed in 21 municipalities located in the northern region of the State of São Paulo (Araçatuba, Cajobi, Descalvado, Guariba, Jaboticabal, Lins, Monte Aprazivel, Pontalinda, São Carlos, São João da Boa Vista, Catiguá, Colina, Fernandópolis, Franca, Orlândia, São José do Rio Preto, Tabapuã, Taiaçu, Taiúva, and Votuporanga (Figure 1). The region studied has a tropical semi-humid climate with two well-defined seasons: a hot, humid, and rainy summer and a mild and dry winter (Nimer, 1989). Table 1 shows the municipalities, number of herds, and samples studied, according to the type of farm. 


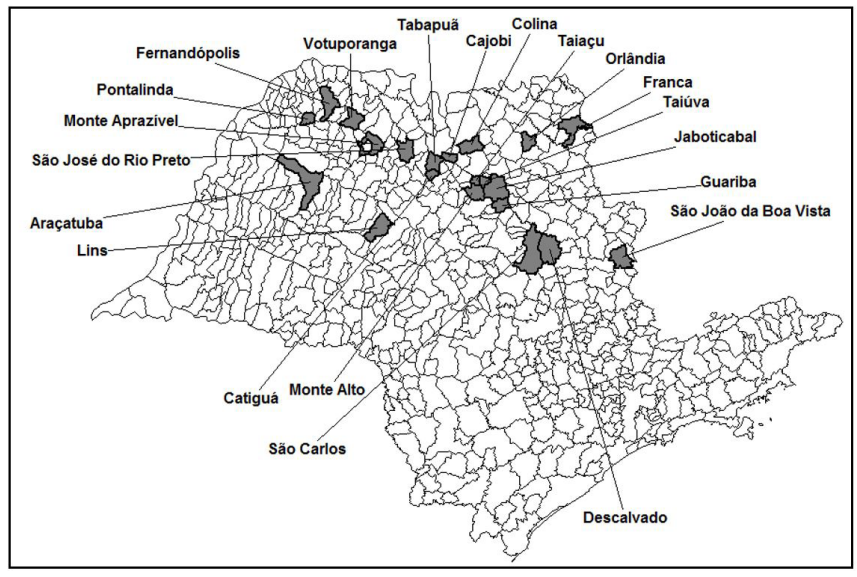

Figure 1. Geographic location of the municipalities of the State of São Paulo, Brazil, where they found the cattle herds sampled for rotavirus detection, from 2006 to 2010.

Table 1. Number of samples collected in dairy and beff herds from 21 municipalities in the northern region of the State of São Paulo, from 2006 to 2010.

\begin{tabular}{cccccc}
\hline municipality & dairy herds & sample & municipality & beef herds & sample \\
\hline Araçatuba & 1 & 45 & Araçatuba & 3 & 23 \\
Cajobi & 1 & 5 & Catiguá & 2 & 15 \\
Descalvado & 10 & 353 & Colina & 2 & 5 \\
Guariba & 1 & 5 & Fernandópolis & 1 & 11 \\
Jaboticabal & 4 & 27 & Franca & 2 & 40 \\
Lins & 1 & 10 & Orlândia & 1 & 5 \\
Monte Alto & 1 & 13 & São José do Rio Preto & 1 & 9 \\
Monte Aprazível & 1 & 5 & Tabapuã & 1 & 6 \\
Pontalinda & 1 & 1 & & & \\
São Carlos & 1 & 40 & & & \\
São João da Boa Vista & 1 & 6 & & & \\
São José do Rio Preto & 1 & 7 & & & \\
Taiaçu & 7 & 126 & & & \\
Taiúva & 1 & 10 & & & 114 \\
Votuporanga & 3 & 36 & & & \\
Total & 35 & 689 & Total & & \\
\hline
\end{tabular}

The fecal samples were collected directly from the calf with a rectal bulb, placed into identified plastic bags, and stored in refrigerated isothermal boxes and then stored in a freezer at $-20^{\circ} \mathrm{C}$ until analysis.

Fecal rotavirus detection was performed using the PAGE technique described by Herring et al. (1982) and Pereira et al. (1985).

\section{Rotavirus detection by polyacrylamide gel electrophoresis (PAGE)}

Suspensions containing 20\% feces were prepared in Tris-calcium buffer (0.1 M Tris HCl, $1.5 \mathrm{mM} \mathrm{CaCl}_{2}$, $\mathrm{pH}$ 7.3) and were homogenized periodically for 30 min at room temperature. Then, the suspensions were centrifuged at $1030 \times g$ for $15 \mathrm{~min}$. The obtained supernatant was transferred to microtubes, which were used to extract viral RNA or stored at $-20^{\circ} \mathrm{C}$.

Rotavirus RNA was extracted by adding $0.4 \mathrm{~mL}$ of the supernatant from each sample to microtubes containing $40 \mu \mathrm{L}$ of $10 \%$ SDS and incubating the tubes at $37^{\circ} \mathrm{C}$ for $30 \mathrm{~min}$. Then, 
$200 \mu \mathrm{l}$ of distilled phenol and $200 \mu \mathrm{l}$ of chloroform were added. The tubes were incubated at room temperature for $15 \mathrm{~min}$ and then centrifuged at $1030 \times g$ for 10 min. The supernatants were transferred to microtubes containing $40 \mu \mathrm{L}$ of $20 \% \mathrm{NaCl}$ and $1.0 \mathrm{~mL}$ of cold ethanol. The microtubes were vortexed and incubated at $-20^{\circ} \mathrm{C}$ overnight. Next, the microtubes were centrifuged at 4,300 $\times g$ for $30 \mathrm{~min}$, and the supernatants were discarded. The microtubes were inverted on filter paper to dry the pellet, and then resuspended in $15 \mu \mathrm{L}$ of sample dissociator. After incubation at $37^{\circ} \mathrm{C}$ for $30 \mathrm{~min}$, the samples were loaded on to a polyacrylamide gel.

The polyacrylamide gel contained a 30:0.8 acrylamide/bis-acrylamide solution. Rotavirus genome segments were visualized by staining with silver nitrate. A standard bovine rotavirus strain "Nebraska Calf Diarrhea Virus" (NCDV) was used as a positive control.

\section{Electrophoretic profile analysis}

The samples were classified based on the differences in their electrophoretic (migration) profiles according to the method of Lourenço et al. (1981). The migration of the 11 RNA segments in each sample in the polyacrylamide gel were compared to those of the standard NCDV strain and classified into four arrangements: class I (segments 1-4), class II (segments 5 and 6), class III (segments 7-9), and class IV (segments 10 and 11), for group A rotavirus.

\section{Statistical analysis}

The data obtained, including the type of farm (dairy or beef), diarrheal or non-diarrheal sample, and calf age, were analyzed using the statistical program Epi Info ${ }^{\mathrm{TM}}$ (7.1.4). Univariate analysis of the data was performed using the corrected chi-square test ( $p<0.05$ ) according to Thrusfield (2005), which was replaced by Fisher's exact test when necessary. MapInfo Professional (version 7.5) was used to construct geographical maps of the studied municipalities.

\section{Results and discussion}

\section{Detection of rotavirus infection by PAGE}

Analysis of the 803 obtained fecal samples by PAGE showed the presence of rotavirus in $6.1 \%$ (49/803) of the samples and in 33.3\% (16/48) of the herds, showing that rotavirus infection is present in the studied regions. Of the 326 samples from calves with diarrhea, 12.6\% (41/326) were positive. Of the 477 samples collected from animals without diarrhea, only eight samples (1.7\%) were positive. The results and according to the type of exploration are described in Table 2.

Studies performed in other countries indicated large variation in the prevalence rates of rotavirus infection among bovine herds, with prevalence rates of 7-98\%, with a mean of 30-40\% (Dhama et al., 2009). In Brazil, several authors reported the occurrence of rotavirus infection in bovine herds in the State of São Paulo, with different prevalence rates, some of which were similar to that in the present study (Buzinaro \& Freitas, 2002; Jerez et al., 2002; Freitas et al., 2011). The variation among these results may be due differences between the sampled herds, and because most studies on rotavirus in cattle were performed in herds with outbreaks of diarrhea.

Statistical analysis showed that there is a significant association between the presence of rotavirus and the consistency of feces, indicating that rotavirus-positivity is higher among animals with diarrheal feces ( $\mathrm{p}=0.0001, \mathrm{RR}=7.35,95 \% \mathrm{CI}$ : 3.9-18.25). Although other authors have reported that the presence of rotavirus is independent of stool consistency, indicating an

Table 2. General results, according to the type of fecal holding and consistency, of the PAGE technique for the detection of rotavirus in calves from the State of São Paulo, from 2006 to 2010.

\begin{tabular}{cccccc}
\hline municipalities & Herds & $\begin{array}{c}\text { Positive/ } \\
\text { sample (\%) }\end{array}$ & $\begin{array}{c}\text { Positive/ } \\
\text { herds } \\
\text { (\%) }\end{array}$ & $\begin{array}{c}\text { Positive/ } \\
\text { sample } \\
\text { diarrhea (\%) }\end{array}$ & $\begin{array}{c}\text { positive/ } \\
\text { sample } \\
\text { no diarrhea (\%) }\end{array}$ \\
\hline São Paulo & dairy & $23 / 689(3.3 \%)$ & $12 / 35(34.3 \%)$ & $15 / 269(5.6 \%)$ & $8 / 420(1.9 \%)$ \\
& beff & $26 / 114(22.8 \%)$ & $4 / 13(30.8 \%)$ & $26 / 57(45.6 \%)$ & O/57(0) \\
Total & & $49 / 803(6.1 \%)$ & $16 / 48(33.3 \%)$ & $41 / 326(12.6 \%)$ & $8 / 477(1.7 \%)$ \\
\hline
\end{tabular}


asymptomatic carrier condition (Buzinaro \& Freitas, 2002), we suspect that virus-infected calves eliminate a large amount of viral particles in diarrheal feces (1010-1012) during the acute phase of the disease, and thus the virus is more likely to be detected by PAGE (Estes, 2001).

\section{Detection of rotavirus infection in dairy herds by PAGE}

The 35 dairy herds were located in 15 municipalities, and 34.3\% (12/35) of herds had rotavirus positive animals. The 12 herds that had at least one rotavirus-positive sample were located in the municipalities of Araçatuba, Cajobi, Descalvado, Guariba, Pontalinda, Taiaçu, and Votuporanga (Figure 2). Of the 689 fecal samples from dairy herds, 3.3\% (23/689) were positive for rotavirus. Among the diarrheal samples, 5.6\% (15/269) were positive, while 1.9\% (8/420) of the non-diarrheal samples were positive for rotavirus (Table 2). Statistical analysis by the chi-square test revealed a significant relationship between rotavirus detection and diarrhea in dairy herds ( $\mathrm{p}=0.09, \mathrm{RR}=2.89,95 \% \mathrm{CI}: 1.27-7.28)$.

Positive samples were detected in different municipalities, showing that rotavirus plays an important role in the etiology of diarrhea in these localities, which has unfavorable implications for the production of dairy calves. Freitas et al. (2011) also detected a higher occurrence of disease in animals with diarrhea in dairy herds.

The occurrence of rotavirus in dairy calves according to age is presented in Table 3. The data were analyzed by the chi-square test, and the analysis did not show a significant statistical relationship with age.

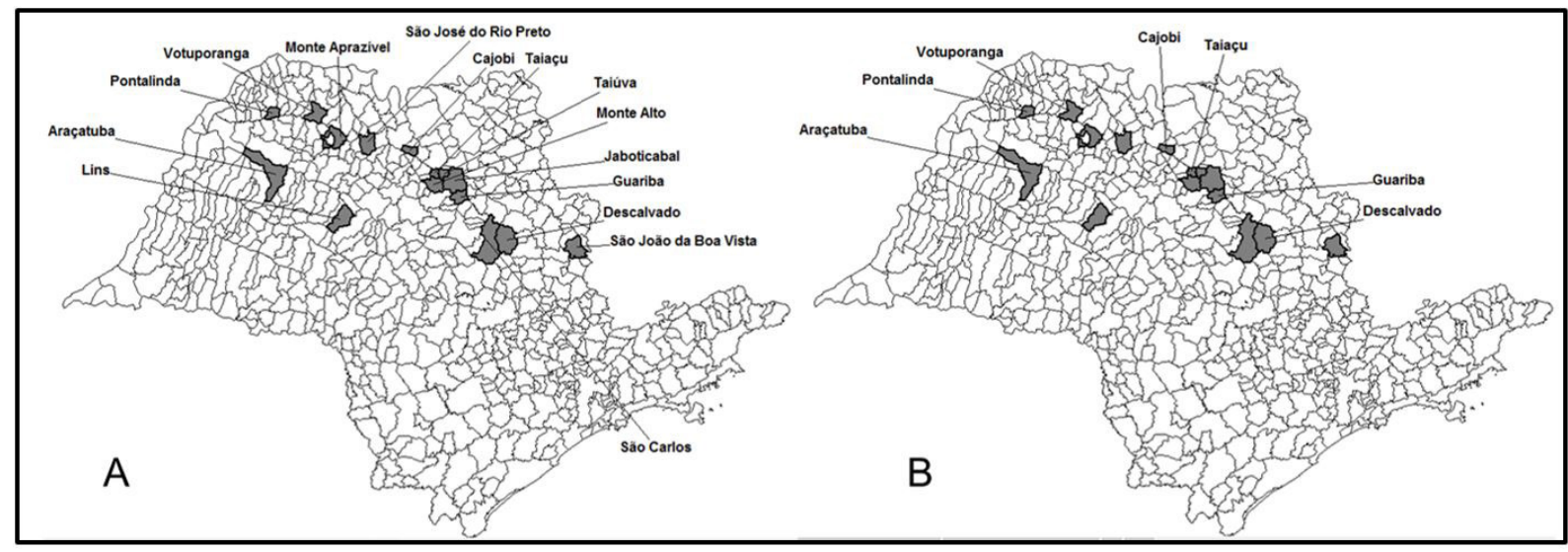

Figure 2. Geographic location of the municipalities of the State of São Paulo, Brazil, where the dairy herds were located (A). Municipalities of the State of São Paulo that had at least one positive animal for rotavirus in the PAGE, in herds of milk, from 2006 to 2010 (B).

Table 3. Positive results in rotavirus PAGE according to the age range of calves in dairy cattle herds in the north of the State of São Paulo, from 2006 to 2010.

\begin{tabular}{cccc}
\hline $\begin{array}{c}\text { Age range } \\
\text { (days) }\end{array}$ & Total & positive(\%)* & Negative \\
\cline { 2 - 4 } & 208 & $8(3.8)^{\mathrm{a}}$ & 200 \\
\hline 1 a 15 & 230 & $10(4.3)^{\mathrm{a}}$ & 220 \\
16 a 30 & 111 & $1(0.9)^{\mathrm{a}}$ & 110 \\
31 a 45 & 67 & $2(3.0)^{\mathrm{a}}$ & 65 \\
46 a 60 & 12 & $1(8.3)^{\mathrm{a}}$ & 11 \\
60 a 90 & 61 & $1(1.6)^{\mathrm{a}}$ & 60 \\
Sem identificação & 689 & $23(3.3)$ & 666 \\
Total & & & \\
\hline
\end{tabular}

*Equal letters in the same column do not differ by the chi-square test ( $p<0.05)$. 
In the dairy herds, calves in all age groups had at least one rotavirus-positive animal. Although previous studies indicate that most cases of rotavirus infection in calves occur in the first weeks of life, as there is a decrease in the immunity conferred by colostral antibodies in the intestinal lumen, which favors infection (McNulty \& Logan, 1983; Lucchelli et al., 1992). However, older calves in dairy herds can also be infected (Buzinaro \& Freitas, 2002). Older animals can carry the infection without showing clinical signs of disease and shed the virus in the environment for a longer period of time.

\section{Detection of rotavirus infection in beef herds by PAGE}

The 13 sampled beef herds were located in eight municipalities, and 30.8\% (4/13) of the herds had at least one rotavirus-positive animal. The four positive herds were located in Araçatuba, Catiguá, and Fernandópolis (Figure 3). Of the 114 samples from beef cattle, 26 (22.8\%) were positive for rotavirus, and all of them were diarrheal samples (26/26), whereas none of the 57 samples of non-diarrheic feces were positive (Table 2 ). Statistical analysis by the chi-square test revealed a significant indefinite relationship $\left(\mathrm{p}=0.7 \times 10^{-10} ; \mathrm{RR}=\right.$ undefined $)$, since there were no positive cases in animals without diarrhea.

The sampled beef herds had a high prevalence of infection (22.8\%), confirming the importance of this virus as an etiological agent of neonatal diarrhea in calves (Alfieri et al., 2006). However, other researchers have found lower prevalence rates in similar studies (Brito, 1994; Freitas et al., 2011). The reproductive management methods used for breeding animals in Brazil, concentrating calving within a short period of time, may facilitate transmission of the virus and increase the prevalence of diarrhea, as previously reported (McNally \& Logan, 1983).

Statistical analysis of the occurrence of rotavirus infection in the herds is shown in Table 4. The results showed a statistically significant relationship between age and the frequency of rotavirus-positive samples ( $\mathrm{p}<0.05$ ). The highest frequencies of infection were observed in animals 1-30 days old, which is similar to the results reported by McNulty \& Logan (1983) and Lucchelli et al. (1992), who found a higher frequency of rotavirus infection in the first two weeks of life.

None of the samples obtained from beef calves older than 31 days were positive by PAGE, although Buzinaro et al. (2003) detected positive calves in this age group in a cut-off herd during an outbreak of diarrhea. Older calves may become more resistant to disease due to decreased viral replication in enterocytes; thus, only highly virulent viral strains can cause diarrhea in older animals (Crawford et al., 2006).

To minimize the occurrence of the disease, vaccination of females at the end of gestation is recommended to increase the amount of antibodies transferred to the calves soon after birth (Fernandez et al., 1998). Vaccination also significantly prolongs the excretion of antibodies in colostrum and milk, thus increasing the resistance of calves to rotavirus infection during this

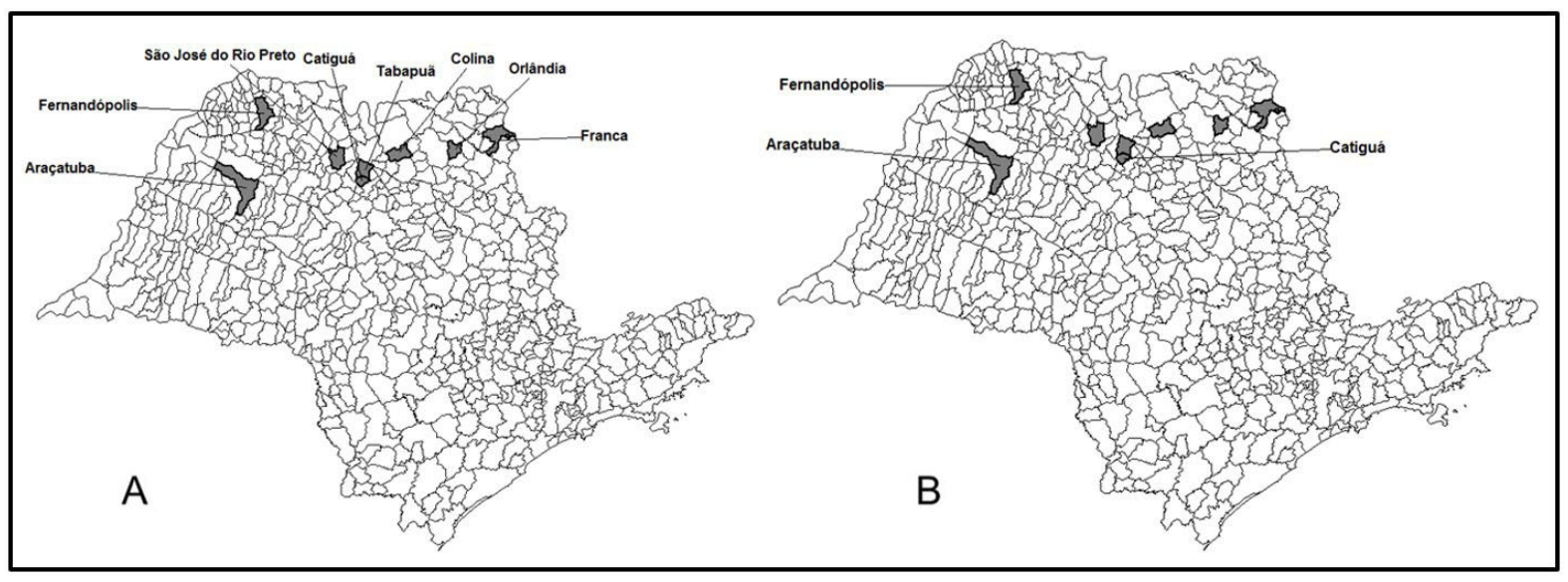

Figure 3. Geographic location of the municipalities of the State of São Paulo, Brazil, where the herds of cut were located (A). Municipalities of the State of São Paulo that had at least one rotavirus positive animal on the PAGE, in herds of cut, from 2006 to 2010 (B). 
Table 4. Positive results in rotavirus PAGE, according to age of calves, in beef cattle from the north of the State of São Paulo, from 2006 to 2010.

\begin{tabular}{cccc}
\hline $\begin{array}{c}\text { Age range } \\
\text { (day) }\end{array}$ & Total & Positive $(\%)^{*}$ & Negative \\
\cline { 2 - 4 } 1 a 15 & 26 & $12(46.2 \%)^{\mathrm{a}, \mathrm{c}}$ & 14 \\
16 a 30 & 23 & $14(60.9 \%)^{\mathrm{a}}$ & 9 \\
31 a 45 & 3 & $0(0)^{\mathrm{a}}$ & 3 \\
46 a 60 & 56 & $0(0)^{\mathrm{b}}$ & 56 \\
60 a 90 & 6 & $0(0)^{\mathrm{c}}$ & 6 \\
Total & 114 & $26(22.8 \%)$ & 88 \\
\hline
\end{tabular}

* Different letters in the same column differ from each other by the chi-square test $(p<0.05)$.

Table 5. Electrophoretic types of bovine rotavirus distributed according to the municipalities and the herds of origin, in calves of dairy herds and of cut of the north of the State of São Paulo, from 2006 to 2010.

\begin{tabular}{|c|c|c|c|c|c|c|c|c|c|c|c|}
\hline \multirow{2}{*}{ herds } & \multirow{2}{*}{ municipalities } & \multirow{2}{*}{$\begin{array}{c}\text { Positive } \\
\text { herds }\end{array}$} & \multirow{2}{*}{$\begin{array}{l}\text { Positive } \\
\text { sample }\end{array}$} & \multicolumn{7}{|c|}{ electrophoretic profile } & \multirow{2}{*}{$\begin{array}{c}\text { samples } \\
\text { were } \\
\text { unclassified }\end{array}$} \\
\hline & & & & $\mathbf{A}$ & B & $\mathrm{C}$ & D & $\mathbf{E}$ & $\mathbf{F}$ & G & \\
\hline \multirow{7}{*}{ dairy } & Araçatuba & 1 & 1 & & & & & & & & 1 \\
\hline & Cajobi & 1 & 1 & & & & & & & & 1 \\
\hline & Descalvado & 5 & 16 & 9 & & 1 & & & & 1 & 5 \\
\hline & Guariba & 1 & 1 & & & & & & & & 1 \\
\hline & Pontalinda & 1 & 1 & & & & & & & & 1 \\
\hline & Taiaçu & 2 & 2 & 1 & & & & & & & 1 \\
\hline & Votuporanga & 1 & 1 & & & & & & & & 1 \\
\hline \multirow{3}{*}{ beef } & Araçatuba & 2 & 15 & & 1 & 5 & 1 & 1 & 6 & & 1 \\
\hline & Catiguá & 1 & 5 & & & & & & & 5 & 0 \\
\hline & Fernandópolis & 1 & 6 & 2 & 1 & & & & & & 3 \\
\hline Total & & 16 & 49 & 12 & 2 & 6 & 1 & 1 & 6 & 6 & 15 \\
\hline
\end{tabular}

period of increased susceptibility (McNally \& Logan, 1983). In the sampled herds, vaccination of pregnant females was not a routine practice. Thus, exposure of animals soon after birth to a contaminated environment may result in rotavirus infection.

\section{Analysis of the electrophoretic profiles of the detected rotavirus genomes}

According to the electrophoretic migration pattern of the rotavirus genome segments in PAGE, the seven detected genomic profiles, characteristic of group A rotaviruses, were randomly named A, B, C, D, E, F, and G. Of the 49 positive samples, 12 were classified as electrophoretic profile A, 2 as profile $B, 6$ as profile $C, 1$ as profile $D, 1$ as profile $E, 6$ as profile $F, 6$ as profile $G$, and 15 samples were unclassified. The results of the electrophoretic analysis are shown in Table 5.

Based on the migration of the rotavirus genomes, three distinct electrophoretic profiles ( $A, C$, and $G$ ) were detected in the dairy herds, while seven different profiles (A, B, C, D, E, F, and G) were detected in the beef herds. The differences were related to the position of the segments in arrangements I and III. Figure 4 shows representative samples of the A, C, F, and G profiles where the migration position of segments 2 and 3 in arrangement I and segments 7, 8, and 9 in arrangement III is verified. 

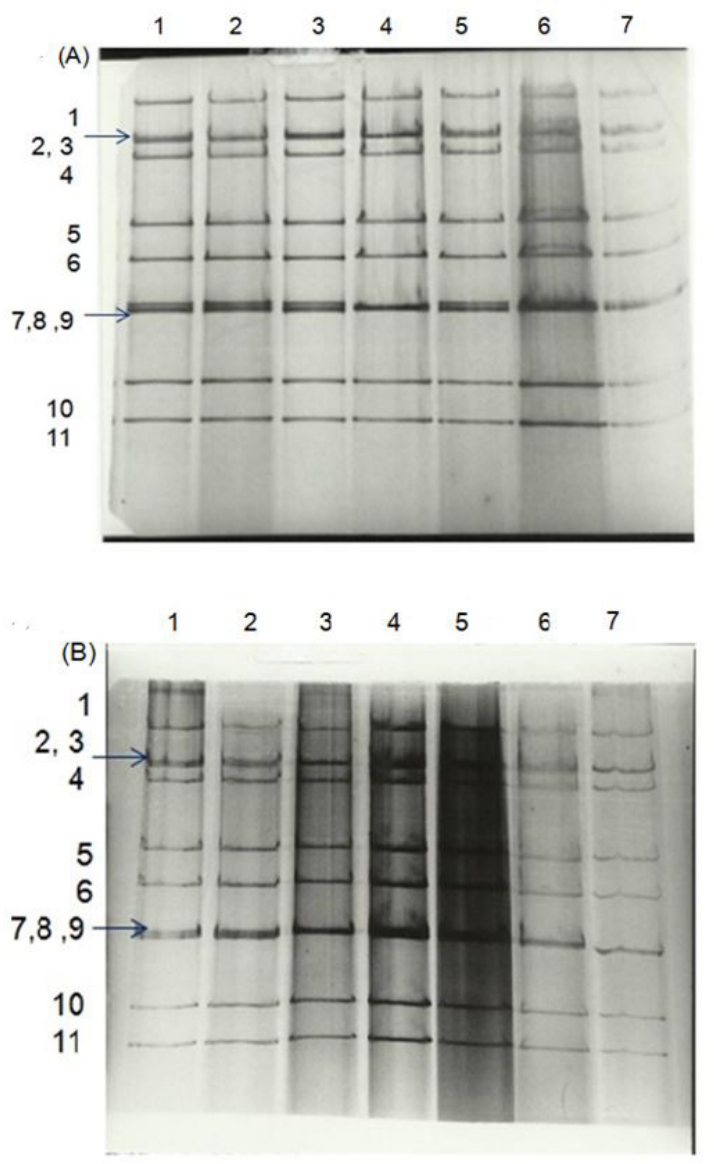

Figure 4. Electrophoretic profile of the rotavirus genome detected in herds of the State of São Paulo. (A) Trough 1, 2, 3, 5, 6 (profile C); 4 (profile F); 7 standard (NCDV); (B) Channels 1, 2, 4 and 5 (profile A); 3, 6 and 7 (profile G); 7 standard (NCDV).

In the dairy herds in the municipality of Descalvado, three electrophoretic profiles were identified (A, $\mathrm{C}$, and $\mathrm{G}$ ), and there was a predominance of type A. In studies of dairy cattle herds conducted by other researchers, great variation in electrophoretic profiles was also detected among the samples (Mendes et al., 1993). Similar results, showing different rotavirus profiles circulating in cattle herds in the State of São Paulo, were obtained in studies conducted by Jerez et al. (1989), Mendes et al. (1993), and Buzinaro et al. (2000).

In the herds of beef cattle in the municipality of Araçatuba, five profiles were detected $(B, C, D, E$, and F), with a predominance of types $C$ and $F$. In the municipality of Catiguá, type $G$ was the only one identified. Similar results were obtained in studies conducted in Argentina (Fijtman et al., 1987) and Japan (Ishizaki et al., 1995), in which little or no genomic diversity was found in the rotavirus strains.

Genome profile analysis by PAGE is a useful technique for distinguishing field strains and providing information. However, the reasons for the occurrence of different electrophoretic types circulating among the calves were not investigated. It should be noted that new variants of the virus may arise in herds, mainly due to the accumulation of point mutations and gene rearrangements facilitated by the segmented nature of the virus, which may alter the viral genome (Matthijnssens et al., 2012).

\section{Conclusions}

Rotavirus infections, which are a major cause of neonatal diarrhea in calves, were present in dairy and beef herds in the northern region of the State of São Paulo, from 2006 to 2010. The prevalence of infection was higher in calves with clinical signs of diarrhea, which affected animals mainly 
in the first month of life. Thus, control and preventative measures are recommended, especially in animals of this age group. The diversity of the electrophoretic profiles suggests that different rotavirus strains can occur in the same herd, justifying the continued study of rotavirus infection in cattle herds and their implications on calf production.

\section{References}

Alfieri, A. A., Parazzi, M. E., Takiuchi, E., Médici, K. C., \& Alfieri, A. F. (2006). Frequency of group A rotavirus in diarrhoeic calves in Brazilian cattle herds, 1998-2002. Tropical Animal Health and Production, 38(7-8), 521526. http://dx.doi.org/10.1007/s11250-006-4349-9. PMid:17265766.

Associação Brasileira das Indústrias Exportadoras de Carne-ABIEC. (2016). Perfil da pecuária no Brasil: relatório Anual 2016. São Paulo: ABIEC. Retrieved in 2018, May 3, from http://abiec.siteoficial.ws/images/upload/ sumario-pt-010217.pdf

Brito, W. M. E. D. (1994). Bovine rotavirus in the State of Goias. Revista de Microbiologia, 25(4), 229-234.

Buzinaro, M. G., Freitas, P. P. S., Samara, S. I., Carvalho, A. A. B., Moreira, S. P. G., \& Jerez, J. A. (2000). Study of bovine rotavirus from dairy herds in northern region of São Paulo State, Brazil. Virus Reviews \& Research, 5(2), 178.

Buzinaro, M. G., \& Freitas, P. P. S. (2002). Rotavírus do grupo A em rebanhos bovinos leiteiros da região Nordeste do Estado de São Paulo. Arquivos do Instituto Biológico, 69(4), 23-26.

Buzinaro, M. G., Mistieri, M. L. A., Carvalho, A. A. B., Samara, S. I., Regitano, L. C. A., \& Jerez, J. A. (2003). Prevalência de rotavírus do grupo A em fezes diarreicas de bezerros de corte em sistema semi-intensivo de produção. Arquivo Brasileiro de Medicina Veterinária e Zootecnia, 55(3), 266-270. http://dx.doi.org/10.1590/ S0102-09352003000300004.

Crawford, S. E., Patel, D. G., Cheng, E., Berkova, Z., Hyser, J. M., Ciarlet, M., Finegold, M. J., Conner, M. E., \& Estes, M. K. (2006). Rotavirus viremia and extra intestinal viral infection in the neonatal rat model. Journal of Virology, 80(10), 4820-4832. http://dx.doi.org/10.1128/JVI.80.10.4820-4832.2006. PMid:16641274.

Dhama, K., Chauhan, R. S., Mahendran, M., \& Malik, S. V. (2009). Rotavirus diarrhea in bovines and other domestic animals. Veterinary Research Communications, 33(1), 1-23. http://dx.doi.org/10.1007/s11259-0089070-x. PMid:18622713.

Estes, M. K. (2001). Rotaviruses and their replication. In D. M. Knipe, P. M. Howley, D. E. Griffin, R. A. Lamb, M. A. Martin, B. Roizman \& S. E. Straus (Eds.), Fields virology (4th ed., pp. 1747-1785). Philadelphia: Lippincott Williams and Wilkins.

Estes, M. K., \& Cohen, J. (1989). Rotavirus gene structure and function. Microbiological Reviews, 53(4), 410-449. PMid:2556635.

Estes, M. K., \& Kapikian, A. Z. 2007. Rotaviruses. In D. M. Knipe, P. M. Howley, D. E. Griffin, R. A. Lamb, M. A. Martin, B. Roizman \& S. E. Straus (Eds.), Fields virology (5th ed., pp. 1917-1974). Philadelphia: Lippincott Williams and Wilkins.

Fernandez, F. M., Conner, M. E., Hodgins, D. C., Parwani, A. V., Nielsen, P. R., Crawford, S. E., Estes, M. K., \& Saif, L. J. (1998). Passive immunity to bovine rotavirus in newborn calves fed colostrum supplements from cows immunized with recombinant SA11 rotavirus core-like particle (CLP) or virus-like particles (VLP) vaccines. Vaccine, 16(5), 507-516. http://dx.doi.org/10.1016/S0264-410X(97)80004-7. PMid:9491505.

Fijtman, N. L., Barrande Guy, M. E., Cornaglia, E. M., \& Schudel, A. (1987). Variations and persistency of eletropherotypes of bovine rotavirus field isolates. Archives of Virology, 96(3-4), 275-281. http://dx.doi. org/10.1007/BF01320968. PMid:2821965.

Freitas, P. P. S., Uyemura, S. A., Silva, D. G., Samara, S. I., \& Buzinaro, M. G. (2011). Rotavírus bovino: fatores de risco, prevalência e caracterização antigenic de amostras em rebanhos leiteiros no Estado de São Paulo. Arquivo Brasileiro de Medicina Veterinária eZootecnia, 63(4), 820-827. http://dx.doi.org/10.1590/S0102-09352011000400005.

Herring, A. J., Inglis, N. F., Ojeh, C. K., Snodgrass, D. R., \& Menzies, J. D. (1982). Rapid diagnosis of rotavirus infection by direct detection of viral nucleic acid in silver-stained polyacrylamide gels. Journal of Clinical Microbiology, 16(3), 473-477. PMid:6182158.

Holland, R. E. (1990). Some infectious causes of diarrhea in young farm animals. Clinical Microbiology Reviews, 3(4), 345-375. http://dx.doi.org/10.1128/CMR.3.4.345. PMid:2224836.

Ishizaki, H., Ohta, C., Shirahata, T., Goto, H., Taniguchi, K., Urasawa, T., \& Urasawa, S. (1995). Persistence of a single eletropherotype and serotype (G6P5) of bovine rotavirus in calves on a closed dairy farm from 1990 to 1993. American Journal of Veterinary Research, 56(8), 1019-1024. PMid:8533972.

Jerez, J. A., Brandão, P. E., Buzinaro, M. G., Gregori, F., Rosales, C. A. R., Ito, F. H., \& Sakai, T. (2002). Detecção de rotavírus e coronavírus em fezes de bezerros neonatos com diarréia criados em vários municípios do Estado de São Paulo, Brasil. Arquivos do Instituto Biológico, 69(2), 19-23.

Jerez, J.A.; Candeias, J.A.N.; Durigon, E.L. et al. Tipos eletroforéticos de rotavirus bovino. Rev. Microbiol.,v.20, p.254-257, 1989

Lourenço, M. H., Nicolas, L. C., Cohen, J., Scherrer, R., \& Bricout, F. (1981). Study of human rotavirus genome by electrophoresis: attempt of classification among strains isolated in France. Annales de l'Institut Pasteur, 132(2), 161-173. http://dx.doi.org/10.1016/S0769-2617(81)80018-4. 
Lucchelli, A., Lance, S. E., Bartlett, P. B., Miller, G. Y., \& Saif, L. J. (1992). Prevalence of bovine group A rotavirus sheddingamong dairy calves in Ohio. American Journal of Veterinary Research, 53(2), 169-174. PMid:1315490.

Matthijnssens, J., Otto, P. H., Ciarlet, M., Desselberger, U., Van Ranst, M., \& Johne, R. (2012). VP6-sequence-based cutoff values as a criterion for rotavirus species demarcation. Archives of Virology, 157(6), 1177-1182. http:// dx.doi.org/10.1007/s00705-012-1273-3. PMid:22430951.

McNulty, M. S., \& Logan, E. F. (1983). Longitudinal survey of rotavirus infection in calves. The Veterinary Record, 113(15), 333-335. http://dx.doi.org/10.1136/vr.113.15.333. PMid:6316619.

Mendes, V. M. C., Beer, M., Peenze, I., \& Steele, A. D. (1993). Molecular epidemiology and subgroup analysis of bovine group A rotaviruses associated with diarrhea in South African calves. Journal of Clinical Microbiology, 31(12), 3333-3335. PMid:8308133.

Nimer, E. (1989). Climatologia do Brasil. Rio de Janeiro: Secretaria de Planejamento e Coordenação da Presidência da República, IBGE.

Pereira, H. G., Azeredo, R. S., Leite, J. P. G., Andrade, Z. P., \& Castro, L. A. (1985). A combined enzyme immunoassay for rotavirus and adenovirus (EIARA). Journal of Virological Methods, 10(1), 21-28. PMid:2982891.

Saif, L. J., Brock, K. V., Redman, D. R., \& Kohler, E. M. (1991). Winter dysentery in dairy herds: electron-microscopic and serological evidence for an association with coronavirus infection. The Veterinary Record, 128(19), 447449. http://dx.doi.org/10.1136/vr.128.19.447. PMid:1650053.

Steele, A. D., Van Niekerk, M. C., \& Mphahlele, M. J. (1995). Geographic distribution of human rotavirus VP4 genotypes and VP7 serotypes in five South African regions. Journal of Clinical Microbiology, 33(6), 1516-1519. PMid:7650177.

Thrusfield, M. (2005). Observational studies. In M. Thrusfield (Ed.), Veterinary epidemiology (3rd ed., pp. 266288). Oxford: Blackwell Publishing. 